\section{'Amalia': A Medium-fruit-size, Heat-tolerant Tomato Cultivar for Tropical Conditions}

\author{
Marta Alvarez Gil, Carlos Moya López, María Elena Dominí Cuadra, \\ and Jorge Arzuaga Sánchez \\ Instituto Nacional de Ciencias Agrícolas, PB 1, 32700 San José de las Lajas, \\ Havana, Cuba
}

\author{
Benedicto Martínez Coca and Simón Pérez Martínez \\ Centro Nacional de Sanidad Agropecuaria, PB 10, 32700 San José de las \\ Lajas, Havana, Cuba
}

Jesús Cuartero Zueco' ${ }^{1}$

Estación Experimental La Mayora, Consejo Superior de Investigaciones Científicas, E-29750 Algarrobo-Costa, Málaga, Spain

Additional index words. Lycopersicon esculentum, fruit set, heat tolerance, Alternaria solani, early blight, disease resistance

The caribbean tropical climate is characterized by two distinct seasons; winter (November to April) and summer (May to October). Winter temperatures range between an average minimum of $17{ }^{\circ} \mathrm{C}$ and an average maximum of 27 ${ }^{\circ} \mathrm{C}$. Summer temperatures (averages minimum $21^{\circ} \mathrm{C}$ and maximum $31^{\circ} \mathrm{C}$ ) delay tomato (Lycopersicon esculentum Mill.) flowering (Atherton and Harris, 1986) and give problems with fruit setting (Geisenberg and Stewart, 1986). Over $80 \%$ of the total annual rain (1300 to $1400 \mathrm{~mm}$ ) occurs in summer and in combination with high temperatures, this produces ideal conditions for the development of early blight [Alternaria solani (Ell. and Mart.) Jones and Grout] disease. Early blight constitutes a serious restraint for tomato production in tropical countries like Cuba (Izquierdo, 1982), Costa Rica (Calvo et al., 1990), and India (Kalloo and Banerjee, 1993) and the Atlantic coast of southern U.S. (Foolad et al., 2000). As a consequence, tomato cannot be profitably cultivated in the summer in Caribbean tropical areas. 'Amalia' combines heat tolerance with early blight resistance and can be cultivated profitably in May through October, maintaining an excellent performance in wintertime, (November to April) thus extending the tomato season for almost the whole year. 'Amalia' may also be useful to tomato breeders as source for breeding heat tolerant hybrids or improved inbred lines.

\section{Origin}

'Amalia' is a released cultivar resulting

Received for publication 23 June 2003. Accepted for publication $12 \mathrm{Jan}$. 2004. This publication is an output from a research project funded by Agencia de Ciencia, Tecnología y Medio Ambiente, Cuba and Secretaría de Estado de Educación y Universidades, Spain. We are grateful to Rafael Fernández-Muñoz, Timothy J. Flowers and Anthony Yeo for helpful suggestions while reviewing the manuscript. ${ }^{1}$ Corresponding author; e-mail cuartero@eelm. csic.es. from a tomato breeding program that started 22 years ago at the Instituto Nacional de Ciencias Agrícolas of Cuba (INCA). The objective of that breeding program was to develop tomato cultivars with medium size fruit, heat-tolerance and early blight resistance.

The pedigree involves crosses between lines followed by successive steps of selfing and selection (Figure 1). Parents of the first cross were 'Campbell-28' and 'INCA-3'. 'Campbell28 ' is a cultivar that is widely grown in tropical countries in winter. It is a small plant with medium-size fruit and foliage which completely covers the fruit. This cultivar is moderately heat-tolerant (Scott, 2000), early blight tolerant, and resistant to Stemphylium solani Webber and to Fusarium oxysporum Schlechtend. f. sp. lycopersici (Sacc.) Snyder race 0. 'INCA-3' is a selected line coming from 'Placero', a heat and early blight tolerant Cuban local landrace. Like 'Placero', 'INCA-3' has good fruit set in both in summer and winter conditions but lacks productivity, and its fruit are not marketable because of low weight ( 55 to $85 \mathrm{~g}$ ), asymmetrical shape and hollow locules.

Two generations were produced each year (winter and summer), and plants with high fruit set were selected in summer. Winter selection was for high fruit production, small plant stature with adequate fruit cover, medium fruit size (weight $>100 \mathrm{~g} /$ fruit) and round-flat fruit shape. To enable early blight infection and disease selections, plants of the early blight susceptible cultivar 'Roma' were planted (each two rows in

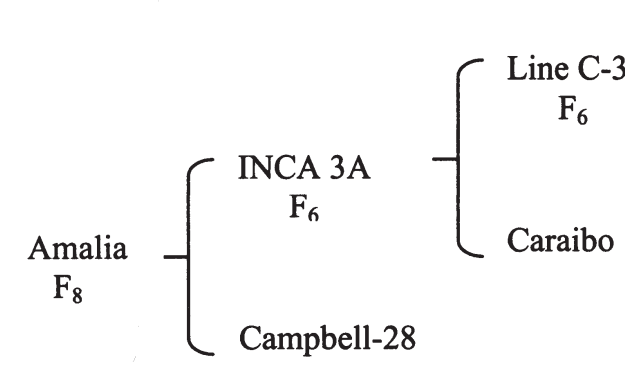

the trials) and no fungicide was applied. Plants were then subsequently scored from 0 to 5 according to the level of early blight symptoms ( 0 without and 5 maximal symptoms). Plants showing the lowest level of early blight were selected in both winter and summer generations. Plants with Stemphylium solani symptoms were discarded.

'Line 35' was selected after three years (six generations of selfing and selection) giving high fruit set in summer and early blight tolerance. 'Line 35' was crossed with 'HC-2580', a high yielding, early cultivar. 'C-3' was obtained after six generations of selfing and selection and then crossed with 'Caraibo' (a cultivar from Guadeloupe Island) to increase fruit size. 'INCA-3A' was obtained after six generations of selfing and then crossed with 'Campbell-28' to improve foliage covering of the fruit. After eight cycles of selfing and selection, three lines ('INCA-A-26-4', 'INCA-A-29-1', and 'INCA-A-1-1') were selected and trialed in two summer and winter seasons in farms at Havana (Camaguiey, Holguín, Santiago de Cuba, and Cienfuegos). 'INCA-A-26-4' performed the best, giving the highest yields ( 25 to $45 \mathrm{t} \cdot \mathrm{ha}^{-1}$ ), early blight resistance and low susceptibility to geminiviruses TYLCV-Is and ToMHV (Quiñonez, 2002) and good acceptance from farmers. 'INCA-A-26-4' was nominated as 'Amalia' and approved for release by the Ministerio de la Agricultura (Cuba, 1997).

\section{Description}

'Amalia' has determinate ( $s p$ ) growth habit with a relatively small upright plant that provides adequate fruit cover. Fruit clusters are held near the erect stem, which prevents fruit contact with the soil. Plants grow vigorously and fruit ripens 5 to $10 \mathrm{~d}$ earlier than 'Campbell-28'. Fruit is medium size (120 to $150 \mathrm{~g}$ in winter, and 80 to $100 \mathrm{~g}$ in summer), round and slightly flattened (68 and $52 \mathrm{~mm}$ equatorial and polar diameter, respectively), with nocracks, orange-red in color at maturity and with minimal rotten fruit even under high rainfall conditions. Soluble solid content is about $5.8^{\circ}$ Brix.

Experiments comparing 'Amalia' and 'Campbell-28' (the most popular cultivar in Cuba) were conducted at INCA facilities during both summer and winter seasons for four years (Table 1). More than $90 \%$ of the flowers

Fig. 1. Pedigree of 'Amalia' inbred tomato.

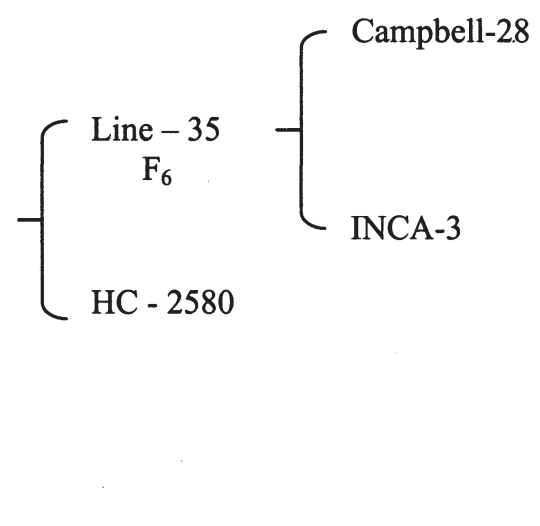


Table 1. Marketable tomato yield (kg/plant), fruit weight $(\mathrm{g})$, and fruit set (\% of flowers produced) in experimental plots at INCA (Havana), in summer (15 Aug. to $15 \mathrm{Sept}$.) and winter (15 Nov. to $15 \mathrm{Dec}$.) seasons from 1996 to 1999 . Harvest period was 4 weeks.

\begin{tabular}{|c|c|c|c|c|c|c|}
\hline \multirow[b]{2}{*}{$\begin{array}{l}\text { Year and } \\
\text { cultivar }\end{array}$} & \multicolumn{3}{|c|}{ Summer } & \multicolumn{3}{|c|}{ Winter } \\
\hline & $\begin{array}{c}\text { Yield } \\
\text { (kg/plant) }\end{array}$ & $\begin{array}{c}\text { Fruit wt } \\
(\mathrm{g})\end{array}$ & $\begin{array}{c}\text { Fruit set } \\
(\%)\end{array}$ & $\begin{array}{c}\text { Yield } \\
\text { (kg/plant) }\end{array}$ & $\begin{array}{c}\text { Fruit wt } \\
(\mathrm{g})\end{array}$ & $\begin{array}{c}\text { Fruit set } \\
(\%)\end{array}$ \\
\hline \multicolumn{7}{|l|}{1996} \\
\hline Amalia & $2.05 \mathrm{a}^{\mathrm{z}}$ & $101.7 \mathrm{a}$ & $96.7 \mathrm{a}$ & $2.90 \mathrm{a}$ & $145.6 \mathrm{a}$ & $98.7 \mathrm{a}$ \\
\hline Campbell-28 & $1.07 \mathrm{~b}$ & $110.1 \mathrm{a}$ & $56.9 \mathrm{~b}$ & $2.30 \mathrm{a}$ & $160.8 \mathrm{a}$ & $92.9 \mathrm{a}$ \\
\hline \multicolumn{7}{|l|}{1997} \\
\hline Amalia & $1.84 \mathrm{a}$ & $99.8 \mathrm{a}$ & $94.5 \mathrm{a}$ & $2.56 \mathrm{a}$ & $129.8 \mathrm{a}$ & $95.3 \mathrm{a}$ \\
\hline Campbell-28 & $0.87 \mathrm{~b}$ & $106.2 \mathrm{a}$ & $49.9 \mathrm{~b}$ & $2.01 \mathrm{a}$ & $142.3 \mathrm{a}$ & $93.2 \mathrm{a}$ \\
\hline \multicolumn{7}{|l|}{1998} \\
\hline Amalia & $1.19 \mathrm{a}$ & $86.7 \mathrm{a}$ & $87.9 \mathrm{a}$ & $2.89 \mathrm{a}$ & $138.7 \mathrm{a}$ & $96.7 \mathrm{a}$ \\
\hline Campbell-28 & $0.51 \mathrm{~b}$ & $89.5 \mathrm{a}$ & $46.3 \mathrm{~b}$ & $2.48 \mathrm{a}$ & $156.2 \mathrm{a}$ & $92.6 \mathrm{a}$ \\
\hline \multicolumn{7}{|l|}{1999} \\
\hline Amalia & $1.79 \mathrm{a}$ & $90.4 \mathrm{a}$ & $90.5 \mathrm{a}$ & $2.64 \mathrm{a}$ & $123.3 \mathrm{a}$ & $95.2 \mathrm{a}$ \\
\hline Campbell-28 & $0.75 \mathrm{~b}$ & $99.3 \mathrm{a}$ & $50.0 \mathrm{~b}$ & $1.99 \mathrm{~b}$ & $132.8 \mathrm{a}$ & $89.1 \mathrm{~b}$ \\
\hline \multicolumn{7}{|l|}{ Average 4 years } \\
\hline Amalia & $1.72 \mathrm{a}$ & $94.4 \mathrm{~b}$ & $92.5 \mathrm{a}$ & $2.75 \mathrm{a}$ & $134.3 \mathrm{~b}$ & $96.5 \mathrm{a}$ \\
\hline Campbell-28 & $0.80 \mathrm{~b}$ & $101.3 \mathrm{a}$ & $50.8 \mathrm{~b}$ & $2.20 \mathrm{~b}$ & $148.2 \mathrm{a}$ & $92.0 \mathrm{~b}$ \\
\hline
\end{tabular}

'Separation of means of 'Amalia' and 'Campbell-28' in each year was made by ANOVA test at $p \leq 0.05$.

Table 2. Marketable yield (t.ha-1) of 'Amalia' and 'Campbell-28' tomatoes grown at Havana, Holguin, and Camagüey locations in Cuba in summer and winter seasons of 1999 and 2000.

\begin{tabular}{|c|c|c|c|c|c|c|}
\hline \multirow[b]{3}{*}{ Cultivar } & \multicolumn{6}{|c|}{ Yield $\left(\mathrm{t} \cdot \mathrm{ha}^{-1}\right)$} \\
\hline & \multicolumn{3}{|c|}{ Summer } & \multicolumn{3}{|c|}{ Winter } \\
\hline & Havana $^{z}$ & Holguin ${ }^{y}$ & Camagüey $^{y}$ & Havana $^{z}$ & Holguin $^{y}$ & Camagüey \\
\hline Amalia & 29.1 & 28.3 & 20.3 & 40.9 & 44.3 & 42.5 \\
\hline Campbell-28 & 19.3 & 15.6 & --- & 33.0 & 29.8 & --- \\
\hline
\end{tabular}

z1999.

y2000.

Table 3. Mean percentage of leaf affected area in the tomato cultivars 'Amalia', 'Campbell-28', 'INIFAT28' and 'Mariela' and in the controls (susceptible 'HC-3880' and tolerant 'NC-EBR-2'), by 18 isolates of Alternaria solani. Cultivars were scored as susceptible (S), resistant (R) or partial resistant (PR).

\begin{tabular}{lcccccc}
\hline & \multicolumn{6}{c}{ Cultivar } \\
\cline { 2 - 7 } Parameter & HC-3880 & Campbell-28 & INIFAT-28 & Mariela & NCEBR-2 & Amalia \\
\hline Percent affected area & 43.1 & 20.1 & 16.5 & 15.6 & 9.0 & 4.7 \\
Resistance & $\mathrm{S}$ & PR & PR & PR & R & R \\
\hline
\end{tabular}

developed by 'Amalia' set marketable fruit in summer. 'Amalia' fruit set was significantly higher than that of 'Campbell-28', a cultivar considered a major source of heat tolerance in the University of Florida's breeding program (Scott, 2000). 'Amalia' fruit weight was slightly lower than that of 'Campbell-28' in both seasons; differences were not significant year by year but they were considering the 4 years together. The higher fruit yield of 'Amalia' in summer sowings in comparison to 'Campbell-28' was mainly explained by the higher fruit set. Fruit set and yield in winter were slightly higher for 'Amalia' than for 'Campbell-28' and although those differences were not significant year by year, they were when all the four years were considered together. Yield in winter was much higher than in summer for both 'Amalia' and 'Campbell-28', which confirmed the difficulty of tomato production in summer conditions. However, 'Amalia' in summer yielded only 25\% less than did 'Campbell-28' in winter.

'Amalia' and 'Campbell-28' were also compared in commercial private farms in three locations in Cuba during 2 years (Table 2). 'Amalia' yields were higher than those of 'Campbell-28' in summer and winter seasons. 'Amalia' in summer yielded 25. $9 \mathrm{t} \cdot \mathrm{ha}^{-1}$, only $20 \%$ less than in winter for 'Campbell-28'. Tomato prices in summer are $25 \%$ higher than winter prices making tomato cultivation profitable in the August to November period. Results indicate that 'Amalia' is better than 'Campbell-28' in winter and it also ensures profitable tomato crops in summer.

Cultivars 'Amalia', 'Campbell-28', 'INIFAT-28', 'Mariela', the susceptible control 'HC-3880' (Pérez et al., 1997) and the resistant control 'NC-EBR-2' (Maiero et al., 1990) were tested for early blight resistance (Table 3). Three detached leaflets of each cultivar were inoculated with mycelium (one of 18 Alternaria solani isolates collected at 18 Cuban locations) and the percentage of leaflet area affected measured. 'Amalia' was identified with high resistance level, similar to 'NC-EBR-2', the resistant control cultivar. Two isolates were able to overcome the resistance of the control (isolates 12 and 195) but only one (isolate 146) surpassed the resistance of 'Amalia'. The artificial infection experiments confirmed the resistance of 'Amalia' previously shown in field conditions.

'Amalia' is also resistant to Stemphylium solani (de Armas, personal communication) an important trait to avoid severe economic losses in tomatoes grown in tropical climates. Quiñonez (2002) by using molecular hybridizations, detected a lower average percentage of infection with any of two begomoviruses, TYLCV-Is (Martínez et al., 1996) and ToMHV (Martínez et al., 1998), in 'Amalia' (46.3\%) than in 'Rilia'
(77.3\%), 'Campbell 28' (76.1\%), 'Lignon' (68\%), and 'HC3880' (60\%), during the open field trials, on the commercial farms for three years of the trial (1999-2001).

\section{Availability}

'Amalia' is an open-pollinated release. Distribution of seed is through the Empresa Nacional de Semillas, Ministerio de la Agricultura, Cuba, esdir@enet.cu. Small amounts of seed for research purposes are available from Dr. C. Jorge Arzuaga Sánchez, INCA, Postal Box 1, 32700, San José de las Lajas, La Habana, Cuba.

\section{Literature Cited}

Atherton, J.G. and G.P. Harris. 1986. Flowering, p. 167-200. In: J.G. Atherton and J. Rudich (eds.). The tomato crop: A scientific basis for improvement. Chapman and Hall, New York.

Calvo, D., J.B. French, J. Siman, and N. Kooper. 1990. Caracterización agroeconómica de la fitoprotección en el cultivo del tomate. Valle central de Costa Rica. Manejo Integrado de Plagas 15:62-82.

Foolad, M.R., N. Ntahimpera, B.J. Christ, and G.Y. Lin. 2000. Comparison of field, greenhouse and detached-leaflet evaluations of tomato germplasm for early blight resistance. Plant Dise. 84:967-972.

Geisenberg, C. and K. Stewart. 1986. Field crop management, p. 511-557. In: J.G. Atherton and J. Rudich (eds.). The tomato crop: A scientific basis for improvement. Chapman and Hall, New York.

Izquierdo, F. 1982. Comportamiento de variedades comerciales y líneas de tomate ante el tizón temprano en el campo durante tres campañas consecutivas de siembra. Revista de Ciencias Biológicas (Havana) 13:87-95.

Kalloo, G. and M. K. Banerjee. 1993. Early blight resistance in Lycopersicon esculentum Mill. transferred from L. pimpinellifolium (Jusl.) Mill. and L. hirsutum. f. glabratum. Gartenbauwissenschaft 58:238-240.

Maiero, M., T. J Ng and T.H. Barksdale. 1990. Genetic resistance to early blight in tomato breeding lines. HortScience 25:344-346.

Martínez, Y.M., I. Zabalgogeazcoa, C. de Blas, F. Sanchez, E.L. Peralta, F. Ponz, and J. Romero. 1996. Geminivirus associated with diseased tomatoes in Cuba. J. Phytopathol. 144:277-279.

Martínez, Y.M., C. de Blas, M. Quiñones, C. Castellanos, E.L. Peralta, and J. Romero. 1998. Havana tomato virus, a new bipartite geminivirus infecting tomatoes in Cuba. Arch. Virol. 143:1757-1772.

Ministerio de la Agricultura. 1997. Lista oficial de variedades comerciales. Ministerio de la Agricultura, Havana, Cuba.

Pérez, S., B. Martínez, and B. Díaz. 1997. Diferenciación de genotipos de tomate por su resistencia a Alternaria solani. Estudio de factores para la potenciación de sus efectos. Rev. Protección Vegetal (Havana) 12:103-108.

Quiñonez, M. 2002. Distribución, variabilidad genética y perfeccionamiento del sistema de diagnóstico para el virus del encrespamiento amarillo de la hoja del tomate (TYLCV) en Cuba. PhD diss. Centro Nacional de Sanidad Agropecuaria, Universidad Agraria de La Habana.

Scott, J.W. 2000. Fla.7771, a medium-large, heattolerant, jointless-pedicel tomato. HortScience 35:968-969. 